http://economix.fr

US Crashes of 2008 and 1929

How did the French market react? An empirical study

Document de Travail

Working Paper

2016-21
Raphael Hekimian

David Le Bris

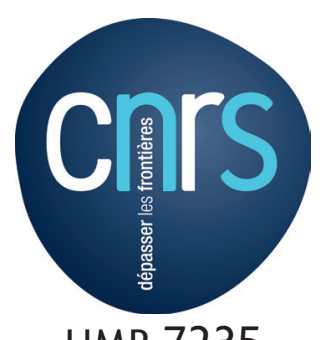

UMR 7235
Université de Paris Ouest Nanterre La Défense (bâtiment G)

200, Avenue de la République 92001 NANTERRE CEDEX

Tél et Fax : 33.(0)1.40.97.59.07 Email :nasam.zaroualete@u-paris10.fr université

Paris Ouest 


\title{
US Crashes of 2008 and 1929 \\ How did the French market react? An empirical study.
}

\author{
Raphael Hekimian* David Le Bris ${ }^{\dagger}$
}

May 30, 2016

\begin{abstract}
We compare the reaction of the Paris bourse to the US crashes during both the 2008 and the 1929 crises. We constitute a new dataset of daily French stock prices from February 1929 to March 1930 that we combine to the already existing daily series of the Dow Jones. We also use newspapers and minutes from the Banque de France and from the Paris Stock Exchange's brokers syndicate in order to confront quantitative data with historical narratives. We finally run contagion tests in both periods, using adjusted correlation coefficients to test for pure contagion. In 1929, the Paris stock market does not exhibit any reaction to the New-York crash. The recent crisis is totally different with a clear contagion of the US crash. This study highlights a significant difference between the two crises and provides strong evidence that the transmission of the Great Depression used other channels than stock markets.
\end{abstract}

JEL Classification: G150, G010, N12, N13

Key Words: Financial history, Financial crisis, Stock market, Contagion

${ }^{*}$ EconomiX-CNRS, UPOND, 200, avenue de la République, 92001 Nanterre, France. Email: raphael.hekimian@yahoo.fr

${ }^{\dagger}$ Kedge Business School, 690, Cours de la Libération, 33405 Talence. Email: david.lebris@gmail.com 


\section{Introduction}

The world has been affected by an economic and a financial crisis started in 2008 in the US. Stock markets all over the world followed New-York in its fall. Most of the economists quite agree that the only comparable crisis is the Great depression of the 1930s (Eichengreen and O'Rourke, 2009; Bordo and James, 2010; Almunia and al., 2010; Fratianni and Giri, 2015). Like the latter, this major event of the 20th century also started in the US before spreading all over the planet. But, focusing on France, this paper shows that the two phenomena exhibit a crucial difference: the French stock market remained perfectly insensitive to the US crash in 1929 while it slumped in 2008. This absence of contagion is consistent with the low integration of the two markets we document in 1929 despite the importance of capital and commercial flows between the two countries. As a consequence, the channels of propagation to the rest of the world of the 1929 and 2008 US crisis world are different.

The US stock market crash is usually seen as the starting point of the Great Depression. The channel(s) through which the US crash propagated to other countries, especially to France, is still an open question. A large part of the debates about the Great Depression has to do with the reasons and mechanisms of this propagation. A first commonly accepted explanation lies in the fixed exchange rates of the Gold Exchange Standard leading to a transmission of negative demand shocks (see for instance Eichengreen, 1992). The financial contagion is also suspected to propagate shocks from one market to another (see Temin, 1993). However, to the best of our knowledge, it seems that up to now, no study has been dedicated to investing whether such a transmission channel was at play, except on inadequate monthly data. This lack can be easily explained by the fact that daily data are difficult to collect in order to observe the short term reactions of foreign stock markets. Thus, even implicitly, most of the existing literature precludes the stock market as an important channel of transmission. This lack has become more problematic since the crisis of 2008 exhibits a very strong correlation among international stock markets after the outbreak of the US crash.

France is one of the most impacted countries by the Great Depression with a fall of about a third of its industrial production. The devaluation of the Sterling in September 1931 has been seen for quite some time as the true starting point of the local version of the Great Depression (Sauvy, 1984). A propagation of the US crash in France could be suspected in 1929 for several reasons. France and US are often seen as having shared similarities at the eve of the Great Depression, such as sharp accumulation of gold and declining consumer prices. The commercial trade between the two countries was as important before 1929 than before 2008. Capital flows were also very large without any capital control. Moreover, during the 1920s, the French stock price enjoyed a rise similar in magnitude to the one observed in New-York.

In this paper, we carefully investigate the short term reaction of the Paris Bourse in the six months following both the US crashes of October 1929 and Lehman failure in 2008. To measure accurately the behavior of the French market in 1929 we build 
a new dataset of daily stock prices collected at the archives of the French Bourse (conserved at the French Ministry of Finance). The French stock market remains surprisingly stable during the US crash. This stability assertion is supported by four kinds of evidence: (1) a descriptive measure of the stability of the French market prices during the US crash, (2) the absence of any structural breaks in the French series in 1929, (3) the stability of the volumes trades in Paris and (4) few narratives of the practitioners of that time.

These evidences provide a clear demonstration that the propagation of the Great Depression is not the result of a contagion of the stock market crash. Thus, we lend support to the common claim of shocks not being transmitted by stock market. To our best knowledge, it is the first study aiming at proving the absence of any contagion of the Wall Street crash to Europe, using data on a daily basis.

A second contribution is the characterization of the relationship between the French and US markets so as to provide a preliminary investigation of the reasons to explain the different reactions to the two US crashes. Previous studies indicate important differences in the behavior of the two markets. The US market exhibits a strong volatility during the Great Depression contrasting to a stable level for the rest of his history (Schwert, 1997). In France, the volatility at its highest is experienced ten years later at the end of the World War II (Le Bris, 2012).

Using our daily dataset, we investigate more deeply the relationship between the two markets in both 1929 and 2008. There is no doubt that the US stock market leads the French one in the recent period but it is less clear in 1929. Despite the leading role of the US economy at that time, the two markets remain broadly independent. We do observe an influence of the US market on the French one but at a weak level. Our evidence joins claims made by Mauro and al. $(2002,2006)$ in which they argue that the modern global financial system suffers from contagion whereas the historical financial system of the pre-world War I era was less prone to it. We show that it is still true during the interwar period, at least between US and France.

An important implication of our research concerns the comparisons that have been flourished since 2008, between these two historical financial crises. Most of these studies stressed the similarities between the two episodes. For example, Peicuti (2014) makes an interesting list of their analogies, highlighting some stylized facts to show the parallels between the periods 1921-1929 and 2001-2007. In particular, the rapid growth without contraction, the increase in global liquidity and the absence of inflation are common to both France and the US for those periods. Moreover, the international spillover effects are a strong common feature of both crises. Grossman and Meissner (2010) also compare the two international crises and try to draw lessons from them in terms of both trade and financial linkages, although without empirical tests. More recently, Mehl (2013) conducted an empirical analysis to assess the role of global volatility shocks, using monthly data spanning from 1885 to 2011. One of his results is that the two most severe global stock market volatility shocks are the late October 1929 stock market crash at the NYSE and the collapse 
of Lehman Brothers in 2008. Our paper tempers the similarities between the two crisis highlighting one crucial difference which is this absence of any contagion from US to France (and one could generalize to continental Europe) after the 1929 Wall street crash.

The remainder of the paper is as follows. After a presentation of the historical context in section 2, the dataset is described in Section 3, Section 4 presents four types of evidences demonstrating the absence of any specific movement in the French stock market in 1929. Section 5 shows a clear contagion in 2008 but not in 1929 . After a brief survey on the contagion literature, we test for the presence of contagion after the crash at the NYSE in both 1929 and 2008., We then implement VAR / VECM models in order to characterize the relationship between the French and the American stock price indexes. In both periods, the returns on the American index seem to have an influence over the French one. Section 6 concludes.

\section{Historical background}

Several characteristics of the 1920s context suggested that the US crash could have found an echo in France. France is often seen in a position similar to the US and sometimes as co-responsible for the Great Depression; "For the positive question of what caused the Depression, we need only note that a monetary contraction began in the United States and France, and was propagated throughout the world by the international monetary standard" (Bernanke and James, 1991). The two countries were accumulating gold at the end of the 1920s; France controlled $17 \%$ of the world's gold reserves in 1929 compared to only 7 \% in 1925 (Irwin, 2010). Indeed, the French franc returned to a form of gold standard in 1926 at an undervalued rate. As a consequence France enjoyed "excessive" trade surplus paid in gold leading to an "excessive" accumulation of gold. The two countries suffered from "self inflicted" price contractions at the eve of the Great Depression with a fall of wholesale prices of $11 \%$ in France between January 1929 and January 1930 and of $4 \%$ in the US (Bernanke and James, 1991). This initial "favorable exchange rate" of the franc in the Gold Exchange Standard did not prevent France from strongly suffering from the Great Depression; the French industrial production of 1937 is $28 \%$ lower than the one observed in 1929 (Landes, 2000 p. 534).

A second reason to expect a transmission of the US crash to France in 1929 lies on the strong commercial links between the two countries. Indeed, the commercial exchanges between the two countries were about the same in 1929 than in 2007. In Table $1,{ }^{1}$ we depict an indicator of the commercial link between the two countries, for 1929 and 2006.

\footnotetext{
${ }^{1}$ We collected the French imports-from and exports-to US in 2006 (US census) we sum these two amounts and divide by the French GDP to obtain a measure of the importance of bilateral trade. The same is done for 1929 using commercial data from the SGF (1931).
} 
Table 1: Trade linkage intensity between France and the U.S.

\begin{tabular}{|l|c|c|}
\hline & 1929 (in billions FRF) & 2006 (in billions \$) \\
\hline Exports to US & 3,33 & 37,04 \\
Imports from US & 7,16 & 23,51 \\
Imports + Exports (I) & 10,49 & 60,55 \\
French GDP (II) & 378,66 & 2325 \\
Trade Exchange (I/II) & $2,77 \%$ & $2,60 \%$ \\
\hline
\end{tabular}

The importance of the trade with the US was slightly higher in 1929 (2.77\% of the French GDP) than in $2006(2.60 \%)$.

A third reason can be found in the situation of the French stock market in 1929. During the 1920s the French stock market exhibited an increase comparable to the one observed in the US. Studying the international correlations among the major world equity markets over 150 years, Goetzmann and al (2001) showed that the correlation between Paris and New York's equity markets during the interwar was at his second highest history just after the recent period. Indeed, after 1921, the two markets both followed an upward trend that remained uninterrupted after 1925 exhibiting roughly the same magnitude (151\% in New-York and $134 \%$ in Paris between January 1926 and October 1929 according to the S\&P and the Historical CAC 40). Moreover, Paris was not a small peripheral market but was seen in the early thirties as the most important financial place of continental Europe (Jacques, 1932).

A last reason stands in the prominence of the capital flows between the two countries. The period we study in our empirical exercise stops in 1930, when controls on capital flows were not that important, allowing large international flows (Obstfeld and Taylor 1997,Mitchener and Wandschneider 2014). In fact, the main controls to capital flows appeared by 1931 and afterwards, when the UK went out of the gold block and imposed controls on foreign exchanges. Apart from standard exchange of capital due to investments, there were flows resulting from the debt of WWI. According to Keynes ${ }^{2}$, the total amount of the debt that France is supposed to reimburse to the US after WWI is 485 millions sterling pounds, which represent roughly one third of the total European indebtedness toward the US. The big picture was that France received German payments and then used this money to reimburse the loans granted by the US as planned by the Dawes (1924) and the Young (1929) plans. France, the second-ranking debtor, did not may anything until 1926, and in the five following years disbursed on average $\$ 32$ million per year to the United States government. The French resented having to surrender a single cent to a people who had appeared on the battlefield belatedly and made such a small human sacrifice compared with their own. But the payment itself registered only minimally in French national accounts. To put the matter into perspective, by 1929, American tourists alone spent $\$ 137$ millions in France (Costigliola 1984).

\footnotetext{
${ }^{2}$ The Collected Writings of John Maynard Keynes, Vol. 16, p. 420.
} 


\section{Data}

Regarding French stock prices during the interwar period, only monthly data are available. The two most common sources are the stock price index of the League of Nations and the one of the Statistique Générale de la France (i.e. the National Institute for Statistics). Both of those indexes are unweighted. More recently, Le Bris and Hautcoeur (2010) constructed a Blue Chips index of French stock prices weighted by market capitalization over 150 years, but the frequency is also monthly.

To build the French market daily prices of 1929, we collected daily spot ${ }^{3}$ prices for forty individual stocks listed at the official list ${ }^{4}$ of the Paris Bourse. Those stocks are the forty highest market capitalizations at the beginning of 1929 as identified by Le Bris and Hautcoeur (2010). Our dataset covers the period from February 1929 through the end of March 1930.

We reconstruct a blue chip weighted index we call HCAC 40 ( $\mathrm{H}$ for Historical), for which the daily return is given by:

$$
R_{H C A C_{t}}=\frac{\sum_{i=0}^{40} \text { number of } \text { share }_{i} \times \text { price of } \text { share }_{t+1}^{i}}{\sum_{i=0}^{40} \text { number of } \text { share }_{i} \times{\text { price of } \text { share }_{t}^{i}}^{i}}-1
$$

For each stock, ${ }^{5}$ we collected the closing price every day. If a stock has no transaction price for a given day, we use the last transaction price in order not to keep the index away from fluctuations due to a lack of liquidity, and not due to a the mechanism of supply and demand.

This index allows us to interpret most of the movements of the French equity market since we know that the aggregated market capitalization of our forty firms represents around $60 \%$ of the total market capitalization of the Paris Bourse at this time (Le Bris and Hautcoeur, 2010). A blue chips index does reflect the overall market (Annaert and al., 2011). The daily data of 2008, spanning from May 2007 up to August 2009, are from Euronext CAC 40. We checked whether our index could be biased since some companies might be more prone to international fluctuations than others. Typically, the banking sector could suffer more from exogenous shocks like the Great Crash of October 1929, while companies which have their business totally grounded in France (e.g. railroads) should be more isolated. For that matter, we made a sectorial analysis (reported in Appendix 1) where we computed a banking index, that include all of the nine banks we have in our database, and a "French only" index that include railroads, utilities and coal mines firms. Figure 5 presented in Appendix 1 shows that the trends seem to be similar between the two sub-indices and the main one. This claim is verified through a simple test on the means and the

\footnotetext{
${ }^{3}$ The Paris Stock Exchange had already a term market and an option market but we only collected prices for the spot market.

${ }^{4}$ There was already an OTC market inside the Paris Bourse, but all the data we collected only concerns the official market.

${ }^{5}$ The complete list of stocks we used are reported in Appendix 1.
} 
variances of the indice returns. ${ }^{6}$

For U.S. data, we use the Dow Jones Industrial index. While the Dow Jones is an inaccurate index for measuring long-term stock performances, since it is weighted by stock prices, it can be useful in the analysis of short term movements. Additionally, it is the single source of daily data for the 1929 period. We also take the Dow Jones for the recent period in order to have the same measure in both periods. ${ }^{7}$

\section{9 in the French stock market: a peaceful pe- riod}

We rely on four types of evidences to demonstrate that the French stock market is not affected by any specific phenomenon in 1929 .

\subsection{Descriptive analysis}

It is well-known that the French market, like other international markets, closely followed the US into the crash after the failure of Lehman brothers (Figure 1). Despite few differences in the behaviours of the two markets prior months, we graphically identify that the two markets evolve closely after the Lehman failure.

Figure 1: Dow Jones and CAC Indices in 2008

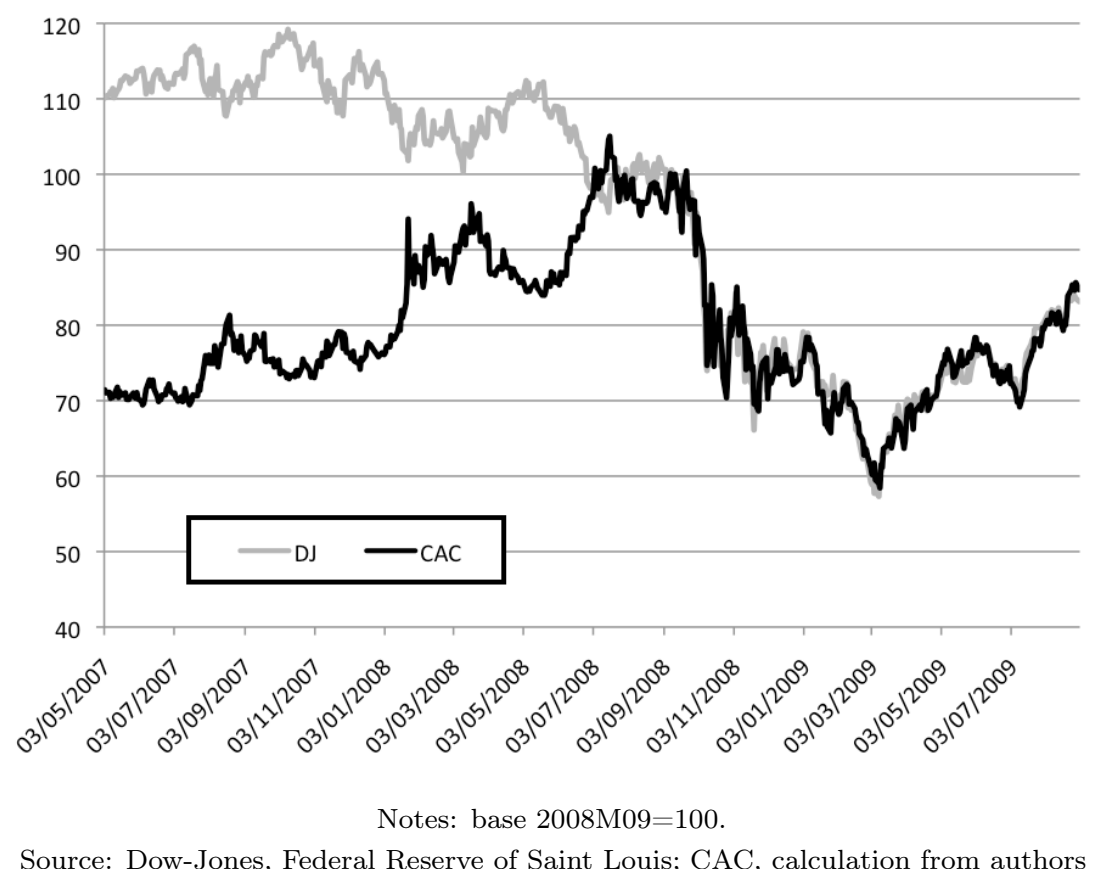

${ }^{6}$ Results are reported in Table 9, in Appendix 1.

${ }^{7}$ We checked if the results would be different by taking the S\&P 500, but the correlations between this later and the Dow Jones is over 0.99 for the period. 
The story is really different when we look at the 1929 case (Figure 2) since no shock occurred on the French stock market after the crash at the NYSE. It is quite surprising to observe that even the worst days in the NYSE seems free of any impact in the Paris market; 1929 October 28, the Dow Jones fell by $13.47 \%$ but our French index decreased by $0.60 \%$ and $2.99 \%$ the day after when the Dow Jones suffered another fall of $11.73 \%$. After these two days, the loss is $23 \%$ in New-York and only $5 \%$ in Paris. The only sharp decrease that we can observe is in late November (red dashed circle), so over a month after the crash. This absence of any contagion of the US crash is really different from what was observed during the last financial crisis.

Figure 2: Dow Jones and CAC Indices in 1929

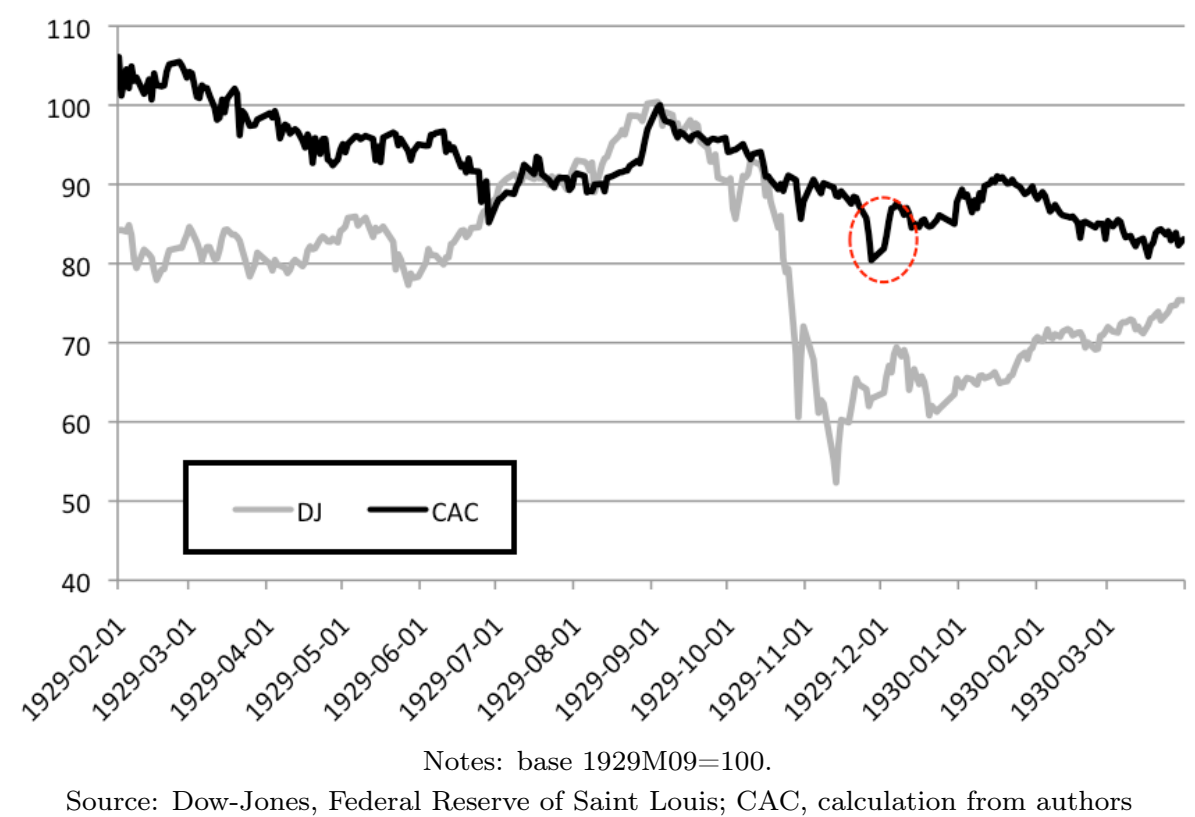

In Appendix 2 are reported the graphs of the returns on the indexes in both periods. We easily observe that the magnitude of the volatility of the French index in 1929 is a lot lower than the American one. It is quite different in 2008, where the magnitude of the volatility is very high for both indexes. Moreover, we can see volatility clusters in each graphs but the French index in 1929: the Historical CAC 40 does not exhibit any particular volatility structure, whereas modern financial series are featured by asymmetric volatility.

\subsection{9 in France does not exhibit any structural break}

A more formalized test for the presence of a specific activity in 1929 in France is to compare the stability of the parameters when we model the stock returns. As in modern series, unit root tests 8 (not reported) lead us to use returns, rather than the series in level to get stationary series. A first glance at the data indicate that the volatility of the returns does not seem to have a particular structure: the high

\footnotetext{
${ }^{8} \mathrm{ADF}$ and Perron tests have been used to detect the trend for both series. Results show that they are all $\mathrm{I}(1)$.
} 
volatilities are not clearly followed by other high volatilities and it is the same for low volatilities. It seems then legitimate to use linear specifications.

We use the Box and Jenkins (1970) methodology in order to specify the best ARMA process to model $R_{C A C_{t}}$. We end up estimating an autoregressive process at the order $1(\mathrm{AR}(1))$ :

$$
R_{C A C_{t}}=\alpha_{0}+\beta_{1} R_{C A C_{t-1}}+\varepsilon_{t}
$$

\begin{tabular}{lllll}
\hline \hline Variables & Coefficient & Std. Error & $t$-statistic & $p$-value \\
\hline$\alpha_{0}$ & -0.0005 & 0.0006 & -0.8051 & 0.42 \\
$\beta_{1}$ & -0.2299 & 0.0555 & -4.1394 & $0.00^{* * *}$ \\
\hline \hline \multicolumn{5}{r}{ Notes: *** denotes significance at the $1 \%$ confidence level. }
\end{tabular}

Table 2: Results

The estimation output shows that the estimated $\beta_{t}$ is significant. Moreover, after testing for the absence of autocorrelation and homoscedasticity ${ }^{9}$ on the residuals, we find that $\varepsilon_{t}$ follow a white noise. It is important to notice that we do not detect any $\mathrm{ARCH}$ effect, which is usually the case for equity returns (especially at a daily frequency). This feature allows us to test for the stability of the parameters. Indeed, since there are no issues on the residuals, we are able to apply a basic Chow test by estimating the model (1) in two sub-samples, before and after the crash at the NYSE in late October 1929.

\begin{tabular}{ccc}
\hline \hline$F$-statistic & Log likelihood ratio & Wald Statistics \\
\hline 2.63 & 5.29 & 5.26 \\
$(0.073)$ & $(0.071)$ & $(0.072)$ \\
\hline Notes: Sample: $2 / 05 / 1929-2 / 31 / 1930$. & $p$-values are reported in parentheses.
\end{tabular}

Table 3: Chow Breakpoint Test: 10/28/1929

The p-value of the $F$-test $(2,296)=0.0736>0.05$ : the null hypothesis is rejected at the $5 \%$ confidence level. The parameters are stable before and after the crash. The crash in New-York is free of any effect on the nature of the stock price variations in Paris. As a robustness check, we applied the Bai and Perron (2003a) breakpoint test that has the advantages of (i) relaxing the assumption of a known breakdate, in addition to (ii) allowing for multiple breaks. Again, the test confirms the Chow test, there are no breakpoints evidenced. Results can be found in Table 10, in the Appendix.

\subsection{The volumes traded in the Paris bourse remain stable}

A third evidence of the absence of any specific phenomenon in France in 1929 is the stability of the volumes exchanged. The increase of the quantity of stocks traded in

\footnotetext{
${ }^{9}$ We used a Ljung-Box test based on the correlogram of the residuals to detect the presence of autocorrelation and an $\mathrm{ARCH}$ test for the homoscedasticity.
} 
NYSE during the crash is a common knowledge. Even in the absence of a violent price movement in France the US crash could have had consequences in the French market through specific movements leading to a rise of the volumes traded.

When researchers in history of finance study the Paris Bourse, a prominent weakness is the lack of data about the volume traded. We tried to solve this issue by collecting two series that we take as proxies for the volumes: the tax on financial transactions and the amount of compensations in between the brokers. However, both series have several limits that we discuss below.

The first one is a tax on financial transactions which is available on bi-monthly basis. The tax levies a fixed rate on the total volume traded at the Paris Bourse for securities listed on the official list, for both the spot and the term markets. Since we only have spot prices, there is an upward bias that is difficult to estimate if we want to link our prices with this volume proxy. We can suppose this bias constant overtime. Moreover, there is a frequency issue because our stock prices are daily and the tax is only available every two weeks. Figure 3 exhibits this series:

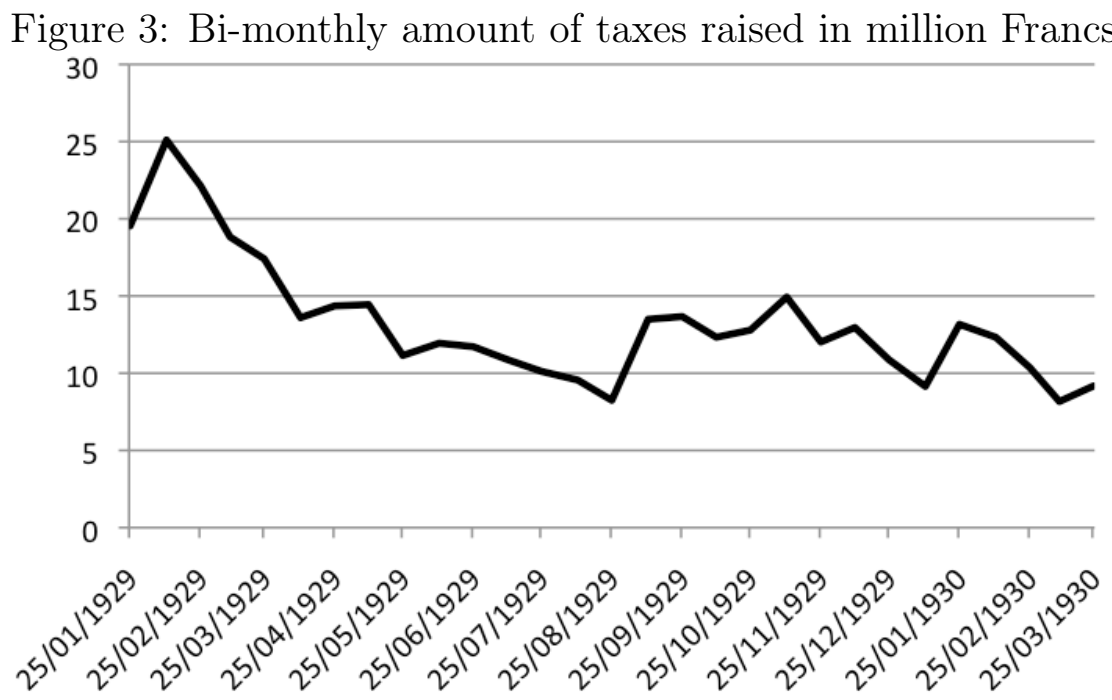

Source: Authors.

Our second proxy for the volume traded is the daily amount of compensations between brokers operating on the official market. Here, the frequency is daily and moreover, it only concerns the spot market. Nevertheless, there is another potential bias, once again very hard to estimate. When a broker executes an order for a client, another broker has to compensate for the amount of the transaction, by an order of his own clients that goes on the opposite way. But if a broker has already two clients giving him opposite orders, he can compensate by himself and then does not have to ask a colleague. In this case, the compensation is not reported in the brokers company's balance sheet. ${ }^{10}$ This also constitutes a downward bias but we can also

\footnotetext{
${ }^{10}$ Until 1987, a brokers company called Compagnie des Agents de Change had the monopoly on all the transactions at the Paris Bourse, but the institution had to remain accountable by the State.
} 
suppose it constant over time. Figure 4 illustrates this series:

Figure 4: Daily compensation in million Francs

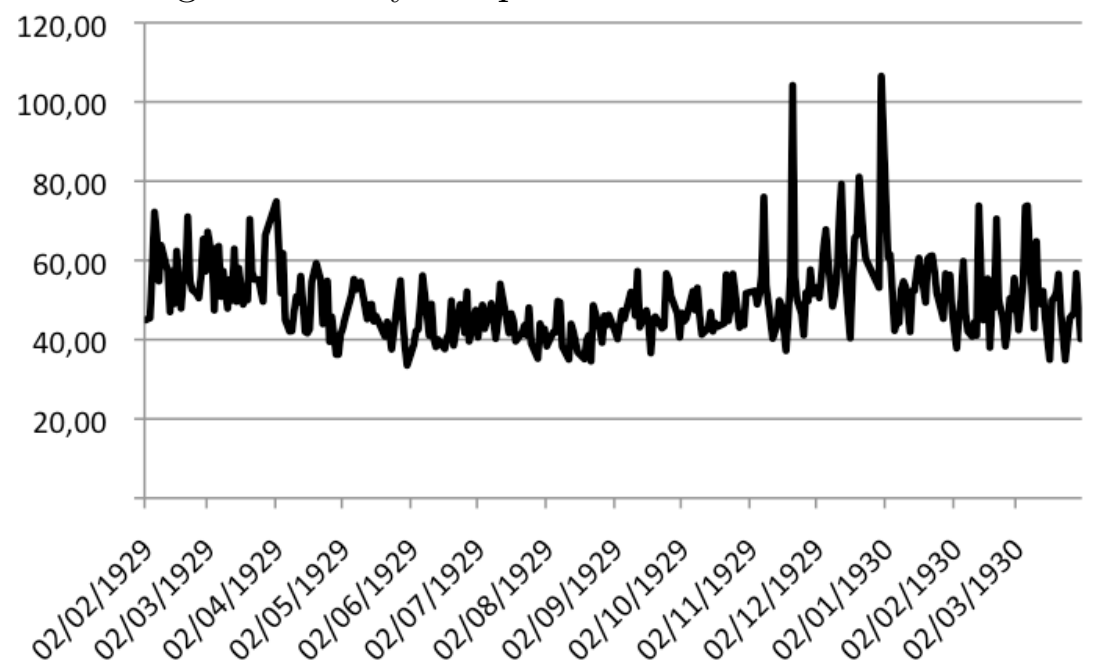

Notes: Source: Authors.

We can see that the volumes are pretty stable except for the end of the year 1929 where some pics appear in November and December, so few weeks after the crash at the NYSE. This seems to indicate some sort of lagged impact on the Paris Stock Exchange, but it contrasts with our descriptive data on prices.

\subsection{Narratives of practitioners}

In this subsection, we look in financial newspapers and in the archives of both the minutes of the Banque de France, and the Compagnie des agents de change. We also looked at some research papers published by French economists at the time. The aim is to check if the story told by the contemporaries fits with our three quantitative evidences previously exposed.

Jean Dessirier (1930), a famous French analyst of the stock exchange, noticed that French asset prices did not follow the downturn of US equity prices. He insists on the French monetary situation, featured by "the maintenance of an easy monetary situation, despite the international tension". He tries to explain that the French stock market hung on because of the nature of French investors comparing to the American ones, much more prone to speculation.

The French monetary situation of the late 1920's and the early 1930's has been much studied in the literature about the Great Depression and it links with the Gold Standard. ${ }^{11}$ This situation is featured by an increasing amount of gold reserves during the period 1927-1932, while the authorities kept the monetary base stable by increasing the cover ratio. We looked at the bi-weekly reports of the board of governors of the Banque de France over the period and found some interesting

\footnotetext{
${ }^{11}$ We can cite, among others, Hamilton (1987), Bernanke and James (1991), Eichengreen and Temin (1996), Irwin (2012).
} 
statements. Indeed, Emile Moreau explicitly warns off against the monetary circulation movements in early $1930^{12}$ and especially in terms of gold inflows coming from abroad. In May 1930, he even plans on decreasing the discount rate after the Bank of England decreased its own, in order not to see more gold inflowing. This suggests that the very first goal of the authorities at this time was to keep the prices stable.

We also looked at the bi-monthly minutes of the Compagnie des Agents de Change. The only time they mentioned a bear market is on December the $5^{t h}$. However, they do not explain the reasons of this downturn. They only focus on the announcement made by the new government that the fiscal surplus will be invested in the economy and therefore that there are no reasons to be pessimistic.

Finally, we went through financial newspapers in order to find some citations that would explain the pics observable on Figure 4, as well as the decrease in the prices depicted on Figure 2 (dashed circle). We can read in Le temps of November the $18^{\text {th }}$ that "rumours on failures in Germany did participate, to a certain extent, in the fall of the prices" and that "before going back to business, the Paris' Bourse is waiting to know the evolution of Wall Street". These quotes suggest that what happens in other financial places seems to influence the behaviour of investors in Paris at that time. However, and more interestingly, the editions of November $21^{s t}$, $22^{\text {nd }}, 26^{\text {th }}$ and $27^{\text {th }}$ all present the same explanation for the slump of late November: a wave of sale orders coming from foreign accounts, "in particular from Germany and Eastern European countries". However, they point out that those sales are quite well absorbed by French investors, which is confirmed by our data because the prices do not fall very sharply and for a short period. Finally, on December the $3^{\text {st }}$ (the second pic on 4), this day is a "liquidation day" (i.e. the day when every term and option contracts are either reported or concluded), which explains partially the increase in the volume. However, it is also mentioned that the monetary situation is playing a large part in the good behaviour of the stock exchange: "The widecomfort of the monetary situation appears, regarding the stock market,at the same time than the excellent position of the stock exchange".

The study of those historical sources seems to confirm the descriptive analysis of our data. In the next section, we make of comparison of the econometrical findings of the study of the relationship between the returns on the Dow Jones the ones of the CAC 40 in both periods.

\section{The presence of contagion in 2008 but not in 1929}

\subsection{A survey on contagion}

The concept of contagion has been widely studied in the economic and financial literature since the early nineties, mostly because of the succession of currency and

\footnotetext{
${ }^{12}$ See bi-weekly minutes of the Banque de France from $1930 / 01 / 02 ; 1930 / 01 / 23 ; 1930 / 01 / 30$; $1930 / 02 / 20 ; 1930 / 03 / 20$.
} 
banking crisis that occurred in emerging markets, such as Mexico in 1994, Thailand in 1997 or Russia in 1998. The common feature of those crises is that they extended to other countries, sometimes to bordering countries, as with Malaysia and Indonesia after the shock in Thailand, but also traveling further, as the one that occurred in Russia, where consequences could be observed, for example, in Brazil. The contagion phenomenon is defined in many ways in the literature. Forbes (2012) lists eleven different definitions ${ }^{13}$ throughout 22 years of research between 1990 and 2012, showing the difficulty of finding a consensus on what do one exactly mean by the word "Contagion". Despite this wide variety of definitions, two main concepts usually describe the mechanism: the fundamental contagion, which is based on macroeconomic fundamentals analysis, and the pure contagion ${ }^{14}$, which results from a change in investors' behavior whose expectations are considered self-fulfilling.

The first approach is particularly well highlighted in Kaminsky and Reinhart (2000). The authors shed lights on this view of contagion by focusing on the transmission channels by which the crisis can spread. They analyze the incidence of both trade and financial sector links. More specifically, their examination of bilateral and third-party trade, the role of international bank lending and the potential cross-market hedging, provides interesting results: first, the probability of a crisis to spread is highly nonlinear: it rises sharply if a group of countries is already infected. Also, they find out that in the episodes of crisis during the 1990s, financial sector links between countries seemed to explain better the contagion, than trade links. However, it is hard to distinguish properly between the two kinds of links.

On the contrary, the second approach does not consider macroeconomic fundamentals but rather focuses on direct interactions between markets or countries. Masson (1998) defines contagion as the result of a change in investors' expectations, regarding the information available. Those expectations being self-fulfilling, the market switches from one equilibrium to another after a country was hit by a shock does not have necessarily strong fundamental links with the infected country. Forbes and Rigobon (2002) make an important distinction between contagion, defined as "a significant increase in cross-market linkages after a shock to one country (or a group of countries)", and the one that could be reffered to as "interdependence" which is characterized by cross-market linkages between countries in crisis times, but also in more tranquil periods. This idea has emphasized the difference between simple correlation and contagion, according to the authors. The subsequent literature on the subject has provided several other definitions in order to refine it. In our paper, we chose to use the one of Boyer and al (2006) because it fits better with the data we collected: "excess correlation between stock markets during periods of high volatility, with "excess" defined as a significant increase in cross-market correlations for investable stocks (relative to less accessible stocks)". Indeed, we justify this choice because of the nature of the index we are studying (i.e. stock price blue chips indexes) and the measure of contagion we chose, as we will see there are several.

\footnotetext{
${ }^{13}$ See in Forbes (2012) Table 1 p. 42.
}

${ }^{14}$ Also known as "shift-contagion." 
But this extensive literature not only provides many definitions of the phenomenon, it has also offered several methods for measuring it. Forbes (2012) summarizes the different methodologies to measure contagion in five general empirical strategies. The first, used in the precursory study of Eichengreen and al. (1996) looks at the probability of the occurrence of a crisis in one country when there is a crisis elsewhere. The use of probabilistic models requires data on many markets (or countries) with many episodes of tranquil / crisis periods while our question is whether contagion occurred between only two countries (France and US) and for two episodes of crisis (1929 and 2008). The second strategy is to focus on crossmarket correlations in order to assess the increase in cross-market linkages after a shock as an evidence of contagion. We will follow this strategy because it fits with our data and with the definition of contagion we opted for. However, this methods has been criticized for being too restrictive since Forbes and Rigobon (2002) showed that markets were actually "interdependant" in all states of the world, and that the increase in the correlation coefficients were due to the high volatilities in crisis periods. The correction of this heteroscedasticity bias has led to much less evidence of contagion. The third strategy identified by Forbes, invovling VAR models, is less conservative. The impulse-response function is used to measure the significancy of the impact of a random shock from one market to the other. Since there is no correction for the heteroscedasticity bias in crisis periods, the evidence of contagion is more frequent in the papers using this method. In response to the issues caused by the analysis of correlation coefficients, researchers have used GARCH specifications in order to assess the spillover effects on the volatility of assets instead of their prices. This fourth approach is interesting because it allows the variance of the returns to vary across regimes. The recent literature using this specification focused on sophisticated forms of GARCH models such as the STCC-GARCH, using a transition variable to assess the switch from tranquil to crisis periods. In most of the literature that uses non-linear models to fit with smooth transition on financial markets, the VIX ${ }^{15}$ is commonly used as the transition variable. But this latter is built with American option prices, assuming that the American stock market is by far the most important one, which is less clear for the interwar period with (at least) an equally important London Stock Exchange. Moreover, to our knowledge, such a variable is impossible to construct for the interwar period since we do not access option prices for either London nor New-York. Finally, a last approach looks at coexceedances and extreme value theory. The idea, introduced by Bae and al. (2003) is to test wether extreme returns are correlated accros markets. This method avoid econometric issues of other approaches but lacks of robustness because the sample of extreme negative returns is often too small, which is the case with our french data.

Now that we surveyed the general literature about contagion, let us look at studies testing for it in our period of interest: the interwar. To the best of our knowledge, three papers have looked at international contagion across financial markets around the Great Depression. Bordo and Murshid (2001) test the existence of contagion for several historical international financial crises, including the interwar period, using adjusted correlation coefficients. However, they use weekly foreign government bond

${ }^{15}$ Usually defined as an index of "implicit" volatility. 
prices traded at the NYSE for several countries, while we focus on only two countries and use daily stock prices traded in each country's stock exchange. We think it makes an important difference because contagion between assets traded within the same stock exchange could be the result of a liquidity stress on this particular stock exchange, whereas the same asset traded in another financial place would not be affected. Accominotti (2011) also looks for potential contagion phenomena during the interwar with a Principal Component Analysis performed on both bond spreads, stock market returns and an index of Exchange Market Pressure. The monthly data used in this paper spread from 1928 to 1936 and the results suggest that the global stress of the early 1930s is mainly due to liquidity issues on the international capital markets, with a pic in 1931 when the UK got out of the Gold Exchange Standard and provoked a capital flow reversal. More recently, Maveyraud and Parent (2015) study the propagation mechanisms of the money market between UK, US and France during the interwar. The authors look at the spilover effect on monthly short term interest rates (3 month) by using a BEKK-GARCH specification with structural break. Their goal is to verify wether their results fit with the Golden Fetters hypothesis of Eichengreen (1992), which is a different question from ours: did the NYSE crash of late 1929 triggered a short term downward spiral in french stock prices? Another difference of our paper with regards to the ones cited above is the frequency of the data. Indeed, we think that monthly data is much less revelant for a contagion study than daily data because too many variations of asset prices might occur within one trading month. With daily data, we expect to catch a lot more information on the impact of a shock originated from another market.

\subsection{Cross market correlations}

Since we did not detect any specific movement in the French stock market in 1929, we should reject a contagion from New-York to Paris. Based on the Forbes and Rigobon (2001, 2002) methodology, we adjust correlation coefficients from the heteroscedasticity bias that occurs during crisis periods. Indeed, volatility increases after shocks on stock markets and the two authors show that the usual correlation coefficients are then biased by construction.

For our two series of stock index returns $R_{D J_{t}}$ and $R_{C A C_{t}}$, the Pearson correlation coefficient is given by:

$$
\rho_{R_{D J_{t}}, R_{C A C_{t}}}=\frac{\operatorname{Cov}\left(R_{D J_{t}}, R_{C A C_{t}}\right)}{\sigma_{R_{D J_{t}}} \times \sigma_{R_{C A C_{t}}}}
$$

Looking at this equation, we notice that a raise in the volatility of the stock market where the crisis occurred, causes a mechanic raise of $\rho$ because the variance of the returns is going to increase in this market after the shock. Therefore, Forbes and Rigobon (2002) propose to calculate an adjusted correlation coefficient given by:

$$
\rho_{i}^{*}=\frac{\rho}{\sqrt{1+\delta\left[1-\rho^{2}\right]}}
$$


with

$$
\delta=\frac{V_{R D J}^{c}}{V_{R D J}^{t}}-1
$$

and $c$ and $t$ respectively represents periods of crisis and tranquility. ${ }^{16} . \delta$ corresponds to the relative increase in the variance after the shock in the country where the crisis occurs.

In order to test the variation in the adjusted correlation coefficient is significant or not between the two sub-periods, we use a Student test with the hypothesis below:

$$
\left\{\begin{array}{l}
H_{0}: \rho_{1}^{*}=\rho_{2}^{*} \\
H_{1}: \rho_{1}^{*}>\rho_{2}^{*}
\end{array}\right.
$$

with $\rho_{1}^{*}$ the adjusted coefficient during the crisis period and in the calm period.

The t-stat is given by:

$$
t=\left(\rho_{1}^{*}-\rho_{2}^{*}\right) \sqrt{\frac{n_{1}+n_{2}-4}{1-\left(\rho_{1}^{*}-\rho_{2}^{*}\right)}}
$$

Table 4 reports the calculation for the two sub-periods. Clearly, the test rejects

1929

2008

\begin{tabular}{lcccc} 
& pre-crisis & post-crisis & pre-crisis & post-crisis \\
\hline \hline$\rho$ & 0.0003 & 0.15 & -0.0379 & 0.1798 \\
$\sigma_{R_{D J}}$ & 0.0133 & 0.0324 & 0.0131 & 0.025 \\
$V_{R_{D J}}$ & 0.0002 & 0.001 & 0.0002 & 0.0006 \\
\hline$\delta$ & \multicolumn{2}{c}{4.935} & \multicolumn{2}{c}{2.642} \\
$\rho_{i}^{*}$ & 0.0001 & 0.0622 & -0.0199 & 0.0953 \\
\hline$t$-stat & \multicolumn{2}{c}{-1.037} & \multicolumn{2}{c}{-2.68} \\
\hline
\end{tabular}

Table 4: Adjusted Correlation Coefficients

the null hypothesis in $2008(|-2.68|>1.96)$ but not in $1929(|-1.037|<1.96)$. This result confirms our precedent evidences that there was no impact of the NYSE crash at the Paris Stock Exchange. However, this contrasts with the fact that in our VAR (1) specification, the returns of the Dow Jones should have an influence over the Historical CAC 40 in 1929 as will be explained below.

\subsection{VAR specification}

As a general explanation of the difference in the reaction of the French market to the US crashes of 1929 and 2008, we assess the relationship between the two markets in both periods. This measure of the nature of the relationship remain open the

\footnotetext{
${ }^{16}$ The crisis period starts in October for 1929 and in Septbember 2008 for the recent period.
} 
question of the fundamental causes. We use VAR/VECM specifications in order to characterize the relationship between $R_{C A C_{t}}$ and $R_{D J_{t}}$. Such model has been firstly used for lower frequency (i.e. monthly or yearly) macroeconomic time series, starting with Sims (1980). However, studies such as Masih and Masih (1997) use this methodology on daily financial time series to analyse the impact of the $1987 \mathrm{crash}$ on the co-movements among different markets. Chien-Chung Nieh and Cheng-Few Lee (2001) also use it to characterize the relationship between stock prices and exchange rates among the G7 countries at a daily frequency.

In this paper, we apply those models to see if there are differences in the relationship between the returns in both periods. In addition, as mentioned above, it is also used in the contagion literature in order to assess the impact of a shock emanating from another market ${ }^{17}$. But Forbes (2012) describes this measure as not enough conservative because it generally does not adjust for heteroscedasticity. We therefore also use this methodology to provide us with an indicator of financial interdependence across markets, as in Favero and Giavazzi (2002).

\subsubsection{The co-movements between American and French stock returns in 2008}

The first step is to run a cointegration test in order to find out if there is a common trend in the two series. We run the "trace" test of Johansen (1991). Annexe 2 reports the results of the test and enables us to conclude in favour of a cointegration relationship between $R_{C A C_{t}}$ and $R_{D J_{t}}$. In other words, one can conclude that there exists a long term relationship between the two returns.

This first result leads us to the existence of a Vector Error Correction Model (VECM) to model the dynamics of the relationship between the indexes. In fact, such a model allows us to look for both the long term relationship, which take into account the cointegration, and the short term relationship between the variables. The results of the estimation are reported in Annexe 3, Table 12. We normalized the French index (LCAC in the table), assuming it is our endogenous variable. The estimated cointegration relationship is given by: ${ }^{18}$

$$
L C A C_{t-1}=-2.65+\underset{(20.87)}{1.18} L D J_{t-1}+z_{t-1}
$$

With $z_{t-1}$ the lagged residuals.

Results for the short term relationship are also interesting:

$$
R_{C A C_{t}}=\underset{(-1.06)}{0.0005}-\underset{(-11.37)}{0.45} R_{C A C_{t-1}}+\underset{(24.63)}{0.82} R_{D J_{t-1}}+\underset{(8.01)}{0.35} R_{D J_{t-2}}-\underset{(-3.10)}{0.04} z_{t-1}
$$

The error correction term $z_{t-1}$ is negative and significant. But if we reverse the equation and we take $L D J_{t}$ as endogenous, the error correction term becomes nonsignificant (See Table 12). This result means that there is one restoring force towards

\footnotetext{
${ }^{17}$ See for example Constancio (2012) who uses error correction models to assess contagion during the eurozone crisis.

${ }^{18} t$-stats are reported in parentheses. All results are available in the Appendix 3, Table 12.
} 
the long term equation: the two series co-move in the long term and if there is a deviation from the mean, it is $L C A C_{t}$ that will adjust. $L D J_{t}$ is the driving force in this long term relationship. $R_{C A C_{t}}$ depends significantly on his value lagged once and on the lagged values of $R_{D J_{t}}$. Once again, if we take $R_{D J_{t}}$ as the endogenous variable, we can see that it only depends on his own lagged values but that $R_{D J_{t}}$ has no influence over $R_{D J_{t}}$ in the short term.

Those results are consistent with what we expected: the US market is the leader and the French market follows during that period.

\subsubsection{The co-movements in 1929}

We run the same cointegration test on our 1929 sample, ${ }^{19}$ leading us to rely on a VectorAutoRegressive (VAR) model as we fail to reject the presence of a long-run relationship. First we test for Ganger causality between $R_{C A C_{t}}$ and $R_{D J_{t}}$ in order to choose the endogenous variable. We ran several tests for each number of lags up to 6. Results are reported in Appendix 3. We can see that for any lag from 1 to 6 , the null hypothesis of $R_{D J_{t}}$ not causing $R_{C A C_{t}}$ is rejected, while the opposite is only verified when we take one lag. This suggests we should take $R_{C A C_{t}}$ as endogenous. Following Engle and Granger's methodology (1987), we estimate VAR with $p$ lags, chosen as to minimize the information criteria, hence $p=3$. Finally, we estimate: ${ }^{20}$

$R_{C A C_{t}}=a_{0}+b_{1} R_{C A C_{t-1}}+b_{2} R_{C A C_{t-2}}+b_{3} R_{C A C_{t-3}}+c_{1} R_{D J_{t-1}}+c_{2} R_{D J_{t-2}}+c_{3} R_{D J_{t-2}}+\varepsilon_{t}$

Table 5: Estimation Results of (2)

\begin{tabular}{cccc}
\hline Variable & Coefficient & Std. Error & $t$-statistic \\
\hline \hline$a_{0}$ & -0.0006 & 0.0007 & -0.85 \\
$\mathbf{b}_{\mathbf{1}}$ & $\mathbf{- 0 . 2 2}$ & $\mathbf{0 . 0 6}$ & $\mathbf{- 3 . 8 7}$ \\
$b_{2}$ & -0.01 & 0.06 & -0.24 \\
$b_{3}$ & -0.07 & 0.06 & -1.34 \\
$\mathbf{c}_{\mathbf{1}}$ & $\mathbf{0 . 1 8}$ & $\mathbf{0 . 0 3}$ & $\mathbf{5 . 3 9}$ \\
$c_{2}$ & -0.007 & 0.03 & -0.21 \\
$c_{3}$ & 0.01 & 0.03 & 0.31 \\
\hline
\end{tabular}

As one can note in Table 5, the only significant coefficients are associated with $R_{C A C_{t-1}}$ and $R_{D J_{t-1}}$. This means that the only useful information helping predicting the returns of $R_{C A C_{t}}$ is contained in of $R_{C A C_{t-1}}$ and $R_{D J_{t-1}}$. In this case, we estimate a second $\operatorname{VAR}(\mathrm{p})$ with $\mathrm{p}=1$. The new relationship we estimate is given by:

$$
R_{C A C_{t}}=a_{0}+b_{1} R_{C A C_{t-1}}+c_{1} R_{D J_{t-1}}+\varepsilon_{t}
$$

Nonetheless, for $\mathrm{p}=1$, the results of the Granger causality test show that there are feedback effects, meaning that we can use both variables as endogenous. The

\footnotetext{
${ }^{19}$ Results are reported in Appendix 3, Table 13.

${ }^{20}$ The complete estimation output is reported in Appendix 3.
} 
Table 6: Estimation Results of (3)

\begin{tabular}{cccc}
\hline Variable & Coefficient & Std. Error & $t$-statistic \\
\hline \hline$a_{0}$ & -0.005 & 0.007 & -0.76 \\
$b_{1}$ & $-\mathbf{0 . 2 5}$ & $\mathbf{0 . 0 5}$ & $\mathbf{- 4 . 8 2}$ \\
$c_{1}$ & $\mathbf{0 . 1 8}$ & $\mathbf{0 . 0 3}$ & $\mathbf{5 . 8 2}$ \\
\hline
\end{tabular}

estimation output of the VAR(1) (reported in Annexe 2) gives us the same estimation with $R_{D J_{t}}$ as the endogenous variable:

$$
R_{D J_{t}}=a_{0}+b_{1} R_{C A C_{t-1}}+c_{1} R_{D J_{t-1}}+\varepsilon_{t}
$$

Table 7: Estimation Results of (4)

\begin{tabular}{cccc}
\hline Variable & Coefficient & Std. Error & $t$-statistic \\
\hline \hline$a_{0}$ & -0.0004 & 0.001 & -0.35 \\
$b_{1}$ & $-\mathbf{0 . 2 6}$ & $\mathbf{0 . 0 9}$ & $\mathbf{- 2 . 7 2}$ \\
$c_{1}$ & $\mathbf{0 . 1 1}$ & $\mathbf{0 . 5 7}$ & $\mathbf{1 . 8 6}$ \\
\hline
\end{tabular}

For both equations, the coefficients of the lagged values of the indexes are significant at the $10 \%$ confidence level. Consequently, it is hard to determine which market leads the other, compared to 2008.

However, we observed in this section that the two markets seem to be much less integrated in 1929 compared to 2008. This is interesting in the sense that the indexes we studied do not have cross-listed securities, so the presence of contagion in 2008 in addition with the cointegration relationship between the indexes on the same period is consistent with the presence of herd behaviour between investors all over the planet. It seems like it was very different in 1929.

\section{Conclusion}

This study provides three findings. First, we show that 1929 and 2008 crisis are different in one crucial point which is the international propagation of the US crash. Despite freedom of capital flows and the traditional relations between France and US, there is no crash or event specific movement at the Paris bourse in 1929. Financial globalization does not imply to support international propagation of stock market crisis as recently observed. Second, the French market exhibited a lower volatility at this time even before the crash. Third, this absence of any contagion of the US crash in 1929 confirms that other channels than stock markets explain the spread of the Great Depression from the US to the rest of the world. This absence of contagion of the US crash in 1929 is consistent with the weak relationship between the two markets we observe at this time. 
The independence of the two stock markets at the end of the 1920s calls for the search of fundamental explanations. Several explanations can be listed. The stability of the French stock market in 1929 could be the result of the monetary situation. After the excessive devaluation of the Franc in 1928, France accumulated gold thanks to commercial surplus. These important gold reserves in France could motivate investors to remain invested in French stocks. In addition, we can highlight an important difference between France and the U.S. in terms of money markets. In fact, U.S. companies refinanced themselves with short term credit on the money market via commercial paper. There is no such market in France, but a national "discount system" 21 which might have isolated French companies from international fluctuations on the money market.

It could also be the effect of the nature of the components of the French stock market. Trade openness in advanced economies -defined as the sum of exports and imports scaled by GDP-was twice higher in 2009 than in 1929 (i.e. 80\% vs. 40\%), to take just one metric (Melh, 2013).

Finally, the difference between the financial market integration in both periods emphasized in the paper could be completed by an analysis in terms of interest rate parity.

\footnotetext{
${ }^{21}$ See on this point: Baubeau P. (2004), "Les "Cathédrales de papier" ou la foi dans le crédit. Naissance et subversion du système de l'escompte en France, fin XVIII, premier XXe siècle," PhD dissertation, Université Paris Ouest Nanterre-la Défense
} 


\section{References}

Accominotti, O. (2011), Asymmetric Propagation of Financial Crises During the Great Depression, working paper.

Annaert, J., Buelens, F., Cuyvers, L., De Ceuster, M., Deloof, M., and A. De Schepper (2011), Are blue chip stock market indices good proxies for all-shares market indices? The case of the Brussels Stock Exchange 1833-2005, Financial History Review.

Almunia, M., Benetrix, A., Eichengreen, B., O’Rourke, K. H., and G. Rua (2010), From Great Depression to Great Credit Crisis: similarities, differences and lessons, Economic Policy, 25(62), pp. 219-265.

Bae, K.-H., Karolyi G. A. and R. M. Stulz (2003), A New Approach to Measuring Financial Contagion, Review of Financial Studies 16(3), pp. 717-763.

Bai, J., and P. Perron (2003a), Computation and analysis of multiple structural change models. Journal of Applied Econometrics, 18.1, pp. 1-22.

Bai, J., and P. Perron (2003), Critical values for multiple structural change tests. The Econometrics Journal, 6(1), pp. 72-78.

Baubeau, P. (2004), "Les "Cathédrales de papier" ou la foi dans le crédit. Naissance et subversion du système de l'escompte en France, fin XVIII, premier XXe siècle," PhD dissertation, Université Paris Ouest Nanterre-la Défense

Bernanke, B. S. and H. James. (1991), The Gold Standard, Deflation, and Financial Crisis in the Great Depression: An International Comparison. In Financial Markets and Financial Crises, edited by R. Glenn Hubbard. Chicago: University of Chicago Press.

Bordo, M. and J. Harold (2010), The Great Depression analogy, Financial History Review, Cambridge University Press, vol. 17(02), pp. 127-140.

Bordo, M. and A. P. Murshid (2000), Are Financial Crises Becoming Increasingly More Contagious? What is the Historical Evidence on Contagion?, NBER Working Paper No.7900.

Costigliola F. (1984), Awkward Dominion: American Political, Economic, and Cultural Relations with Europe, 1919-1933, Ithaca: Cornell University Press, p. 173.

Chien-Chung, N. and L. Cheng-Few (2001), Dynamic relationship between stock prices and exchange rates for G-7 countries, The Quarterly Review of Economics and Finance, 41, pp. 477-490.

Boyer, B. H., Kumagai T. and K. Yuan (2006), How Do Crises Spread? Evidence from Accessible and Inaccessible Stock Indices, The Journal of Finance 61(1), pp. 957-1003.

Constancio, V.(2012), Contagion and the European Debt Crisis, Financial Stability Review (Banque de France), 16, pp. 109-121.

Desirier, J. (1930), La bourse de valeur, Revue d'Economie Politique. 
Eichengreen, B. (1986), The Bank of France and the Sterilization of Gold, 19261932, Explorations in Economic History 23(1), pp. 56-84.

Eichengreen, B. (1992), Golden Fetters: The Gold Standard and the Great Depression, Oxford: Oxford University Press.

Eichengreen, B., Rose A. K. and Wyplosz C. (1996), Contagious Currency Crises: First Tests, Scandinavian Journal of Economics 98(4), pp. 463, Äì84.

Eichengreen B. and K. O'Rourke (2009), A Tale of Two Depressions, voxeu.

Favero, C. and F. Giavazzi (2002), Is the International Propagation of Shocks NonLinear?: Evidence from the ERM, Journal of International Economics, 51, pp. 231246.

Forbes, K. and R. Rigobon (2001), Measuring contagion: conceptual and empirical issues. In International financial contagion, Ed. Springer US, pp. 43-66.

Forbes, K. and R. Rigobon (2002), No Contagion, Only Interdependence : Measuring Stock Market Comovements, The Journal of Finance, October, pp. 2223-2261.

Forbes, K. J., The Big C: Identifying and Mitigating Contagion, NBER Working Paper No. 18465.

Fratianni, M. and F. Giri (2015), The Tale of Two Great Crises, FinMaP-Working Paper, No. 51.

Goetzmann, W. N., Lingfeng L., and R. Geert (2001), Long-Term Global Market Correlations, NBER Working Paper No. 8612.

Grossman, R. S. and C. M. Meissner (2010), International Aspects of the Great Depression and the Crisis of 2007: Similarities, Differences, and Lessons, NBER Working Paper No. 16269.

Irwin, D. (2010), Did France Cause the Great Depression?, NBER working paper No. 16350.

Jacques, R. (1932), Paris peut-il remplacer Londres comme Marché financier international ?, Revue d'Economie Politique, janvier-février.

Kaminsky, G. L. and C. M. Reinhart (2000), On crises, contagion, and confusion, Journal of International Economics 51(1), pp. 145-168.

Keynes J.-M., The Activities 1914-1919: V 16: the Treasury and Versailles Collected Works of Keynes by Johnson, Elizabeth Ed John Maynard Keynes, Palgrave Macmillan (1971).

Landes, D. (2000), L'Europe technicienne, Paris, Gallimard.

Le Bris, D. and P. C. Hautcoeur (2010), A challenge to triumphant optimists? A blue chips index for the Paris stock exchange, 1854-2007, Financial History Review.

Le Bris, D. (2012), La volatilité des actions françaises sur le long terme, Revue Economique, 63.3, pp. 569-580.

Masih, A. M. and R. Masih (1997), Dynamic Linkages and the Propagation Mechanism Driving Major International Stock Markets: An Analysis of the Pre- and 
Post-Crash Eras, The Quarterly Review of Economics and Finance, Vol. 37(4).

Masson, P. R. (1999), Multiple Equilibria, Contagion, and the Emerging Market Crises, IMF Working Paper No 99/164.

Maveyraud S. and A. Parent (2015), The international contagion of short-run interest rates during the Great Depression, Cahiers du GRETha No. 2051-11. Mauro, P., Sussman, N., and Y. Yafeh (2002), Emerging Market Spreads: Then Versus Now, Quarterly Journal of Economics, 117.2, pp. 695-733.

Mauro, P., Sussman, N., and Y. Yafeh (2006), Emerging Markets and Financial Globalization: Sovereign Bond Spreads in 1870-1913 and Today, Oxford, Oxford University Press.

Melh, A. (2013), Large Global Volatility Shocks, Equity Markets and Globalisation 1885-2011, ECB Working Paper No. 1548.

Mitchener, K. J. and K. Wandschneider (2014), Capital Controls and Recovery From the Financial Crisis of the 1930s, NBER Working paper No. 2022.

Obstfeld, M., A. M. Taylor (1997), The Great Depression as a Watershed: International Capital Mobility Over the Long Run, NBER Working Paper No. 5960.

Peicuti, C. (2014), The Great Depression and the Great Recession: A comparative Analysis of their Analogies, MPRA Working paper No. 57883.

Sauvy, A. (1984), Histoire Economique de la France entre les deux guerres, Vol. 3, Paris, Economica.

Schwert, G. (1997), Stock Market Volatility: Ten Years after the Crash, NBER Working paper No. 6381.

Temin, P. (1993), Transmission of the Great Depression. Journal of Economic Perspectives, 7(2), pp. 87-102. 


\section{Appendix 1}

Table 8: Index Composition

\begin{tabular}{|c|c|c|c|c|}
\hline Security & $\begin{array}{l}\text { Share in } \\
\text { the index }\end{array}$ & $\begin{array}{c}\text { Number of } \\
\text { shares }\end{array}$ & $\begin{array}{c}\text { Price on } \\
\text { January } 4^{t h} 1929\end{array}$ & $\begin{array}{c}\text { Market } \\
\text { capitalization }\end{array}$ \\
\hline Canal maritime de Suez & $17,87 \%$ & 446796 & 24600 & 10991181600 \\
\hline Banque de France & $6,97 \%$ & 182500 & 23500 & 4288750000 \\
\hline Saint Gobain & $5,44 \%$ & 410000 & 8160 & 3345600000 \\
\hline Crédit Foncier de France & $4,88 \%$ & 600000 & 5000 & 3000000000 \\
\hline Brasseries Argentine Quilmes & $3,53 \%$ & 240000 & 9040 & 2169600000 \\
\hline Mines de Lens SC & $3,37 \%$ & 2050000 & 1010 & 2070500000 \\
\hline Banque de Paris et des Pays-Bas & $3,34 \%$ & 400000 & 5140 & 2056000000 \\
\hline Crédit Lyonnais & $3,32 \%$ & 500000 & 4090 & 2045000000 \\
\hline Banque de l'Indo-Chine & $3,24 \%$ & 144000 & 13850 & 1994400000 \\
\hline Société Générale & $3,06 \%$ & 1000000 & 1880 & 1880000000 \\
\hline Cie des produits chimiques d'Alais et Camargue & $2,71 \%$ & 400000 & 4170 & 1668000000 \\
\hline Mines de Courrières & $2,48 \%$ & 1080000 & 1411 & 1523880000 \\
\hline Nord (Chemins de fer) & $1,96 \%$ & 525000 & 2300 & 1207500000 \\
\hline Mines de Marles & $1,96 \%$ & 1040000 & 1160 & 1206400000 \\
\hline Comptoir National d'Escompte & $1,91 \%$ & 500000 & 2355 & 1177500000 \\
\hline Paris Lyon Méditérannée & $1,90 \%$ & 800000 & 1460 & 1168000000 \\
\hline Mines d'Anzin & $1,77 \%$ & 400600 & 2725 & 1091635000 \\
\hline Etb Kuhlmann & $1,63 \%$ & 720000 & 1395 & 1004400000 \\
\hline Banque de l'Union Parisienne & $1,56 \%$ & 300000 & 3190 & 957000000 \\
\hline Banque de l'Algérie & $1,47 \%$ & 50000 & 18050 & 902500000 \\
\hline Raffinerie Say & $1,46 \%$ & 368156 & 2440 & 898300640 \\
\hline Mines d'Aniche & $1,41 \%$ & 320000 & 2715 & 868800000 \\
\hline Sarre et Moselle & $1,41 \%$ & 400000 & 2170 & 868000000 \\
\hline Houilles de Blanzy & $1,40 \%$ & 600000 & 1435 & 861000000 \\
\hline Banque Nationale de Crédit & $1,39 \%$ & 500000 & 1705 & 852500000 \\
\hline Cie Parisienne de distribution d'électricité & $1,39 \%$ & 400000 & 2130 & 852000000 \\
\hline Sté Lyonnaise des Eaux et d'Eclairage AJ & $1,38 \%$ & 250000 & 3390 & 847500000 \\
\hline Mines de Vicoigne et Noeux SC & $1,35 \%$ & 600000 & 1380 & 828000000 \\
\hline Charbonnages du Tonkin & $1,33 \%$ & 64000 & 12800 & 819200000 \\
\hline Union d'électricité & $1,31 \%$ & 800000 & 1008 & 806400000 \\
\hline Air Liquide & $1,30 \%$ & 600000 & 1335 & 801000000 \\
\hline Penarroya & $1,28 \%$ & 585000 & 1345 & 786825000 \\
\hline Orléans (Chemins de fer) & $1,22 \%$ & 600000 & 1255 & 753000000 \\
\hline Cie de Béthune & $1,19 \%$ & 85000 & 8600 & 731000000 \\
\hline Forges et Aciéries du Nord et de l'Est & $1,18 \%$ & 440000 & 1655 & 728200000 \\
\hline Citroën & $1,14 \%$ & 400000 & 1760 & 704000000 \\
\hline Mines de Dourges SC & $1,14 \%$ & 285000 & 2460 & 701100000 \\
\hline Est-Lumière & $1,13 \%$ & 675000 & 1026 & 692550000 \\
\hline Ouest Parisien & $1,12 \%$ & 840000 & 820 & 688800000 \\
\hline Est (Chemins de fer) & $1,10 \%$ & 584000 & 1160 & 677440000 \\
\hline Total & $100 \%$ & & & 6151346224 \\
\hline
\end{tabular}

Notes: In francs. Source: Authors. 
Figure 5: Sub-indices in 1929

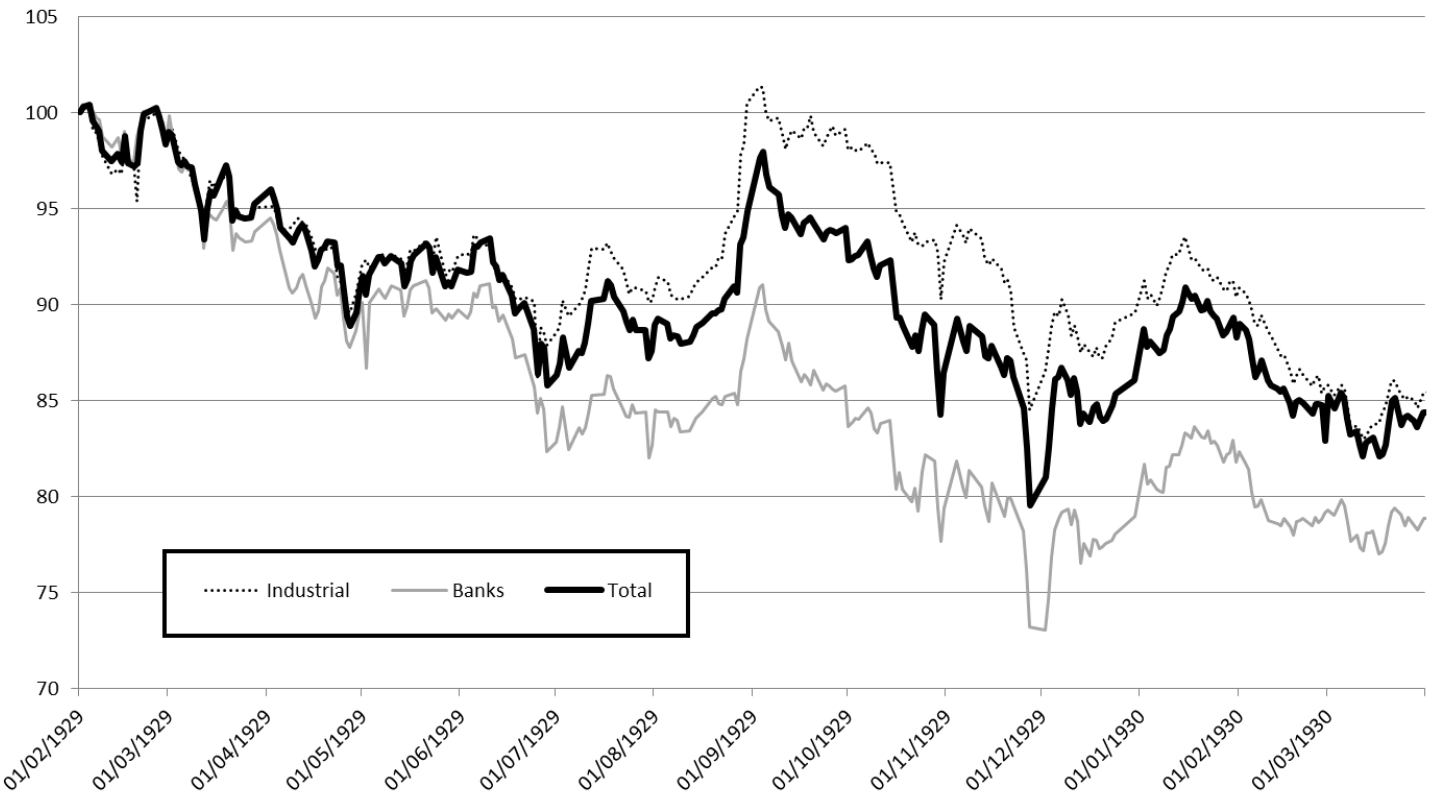

Notes: base $1929 \mathrm{M} 02=100$. Source: calculation from authors

Table 9: Sub-Indices (Industrial, Banks) vs. Total (HCAC 40) index

\begin{tabular}{lcc} 
& Mean & Variance \\
\hline \hline Variable & $t$-test & $F$-test \\
\hline Industrial & -0.149 & 1.364 \\
& $(0.88)$ & $(0.007)$ \\
Banks & 0.260 & 1.219 \\
& $(0.79)$ & $(0.08)$ \\
\hline
\end{tabular}

Notes: Tests were applied on stationary data. ${ }^{a}$ denotes rejection of the null of equality in mean (or variance). $p$ -values are reported in parentheses.

\section{Appendix 2}

Historical CAC 40

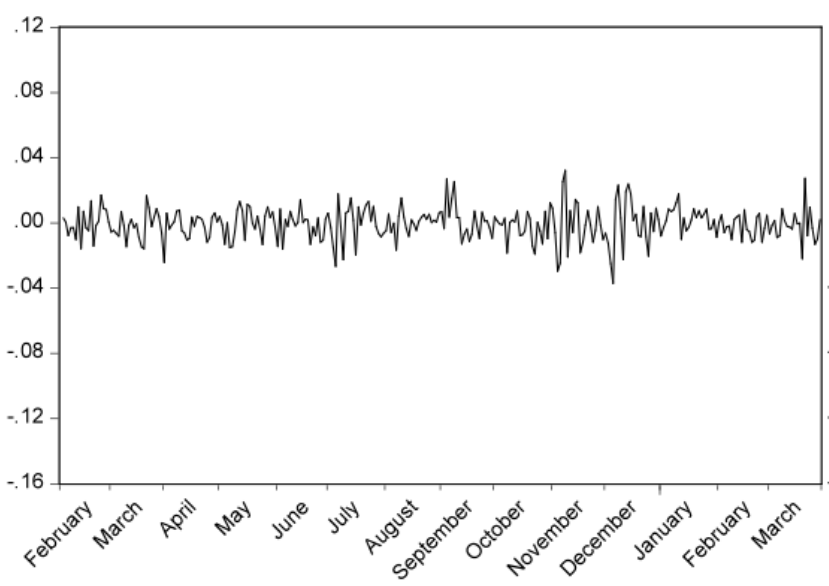

30
Dow Jones

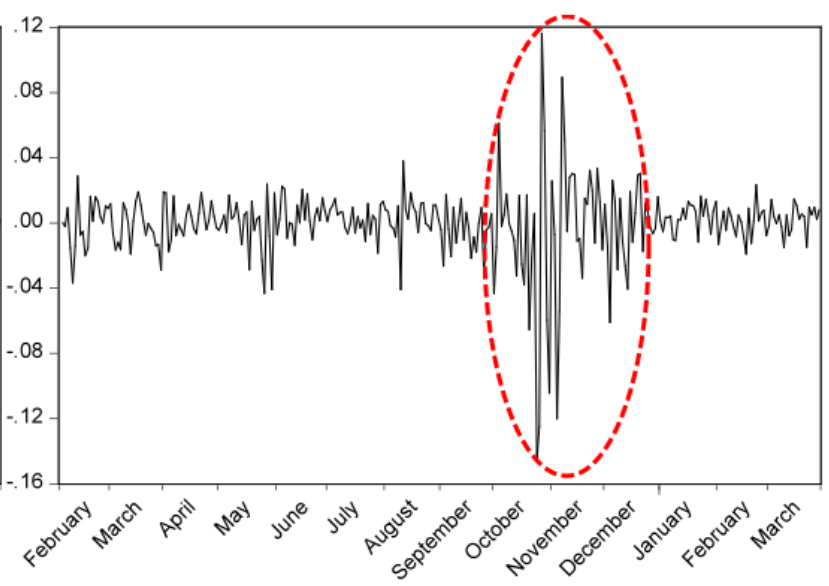

Figure 6: Stock returns volatility in 1929 

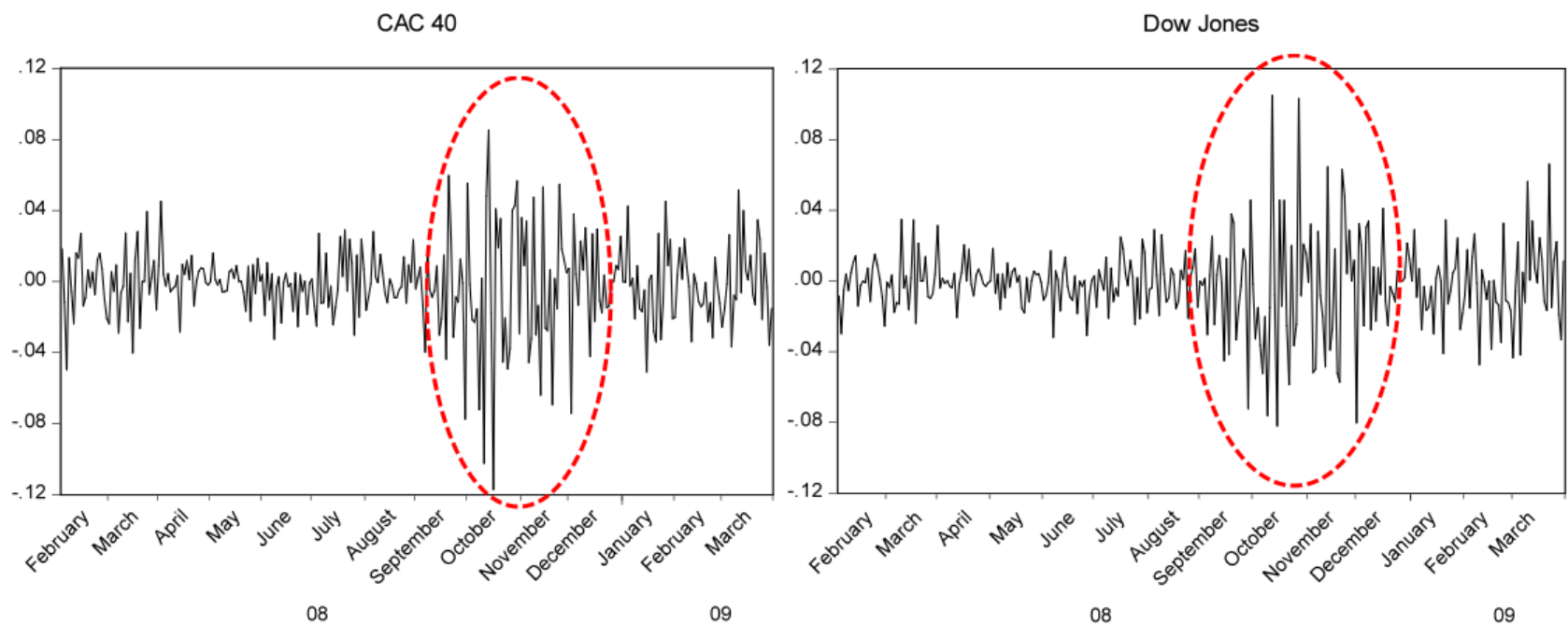

Figure 7: Stock returns volatility in 2008

Table 10: Robustness - Bai and Perron (2003) multiple breakpoint test

Test of $1+L$ globally determined breaks

\begin{tabular}{lccc}
\hline Breaks & F-Statistic & Weighted F-Statistic & Critical Value \\
1 & 1.61 & 1.61 & 8.58 \\
2 & 3.05 & 3.63 & 7.22 \\
3 & 3.12 & 4.50 & 5.96 \\
\hline
\end{tabular}

Test of $L+1$ vs. $L$ sequentially determined breaks

\begin{tabular}{llll}
\hline Break Test & F-Statistic & Weighted F-Statistic Critical Value*
\end{tabular}

\begin{tabular}{llll}
0 vs. 1 & 1.61 & 1.61 & 8.58 \\
\hline
\end{tabular}

Notes. * refers to critical values computed by Bai and Perron (2003). We employ a trimming percentage on the data of $15 \%$. To allow for a serial correlation in the errors, we specify a quadratic spectral kernel based on HAC covariance estima-tion using pre-weighted residuals. In each case, the statistics do not exceed the critical values, therefore we do not reject the null hypothesis of no breaks in the $L C A C$ series. 


\section{Appendix 3}

- $\underline{\text { The Great Recession }}$

ШDJ

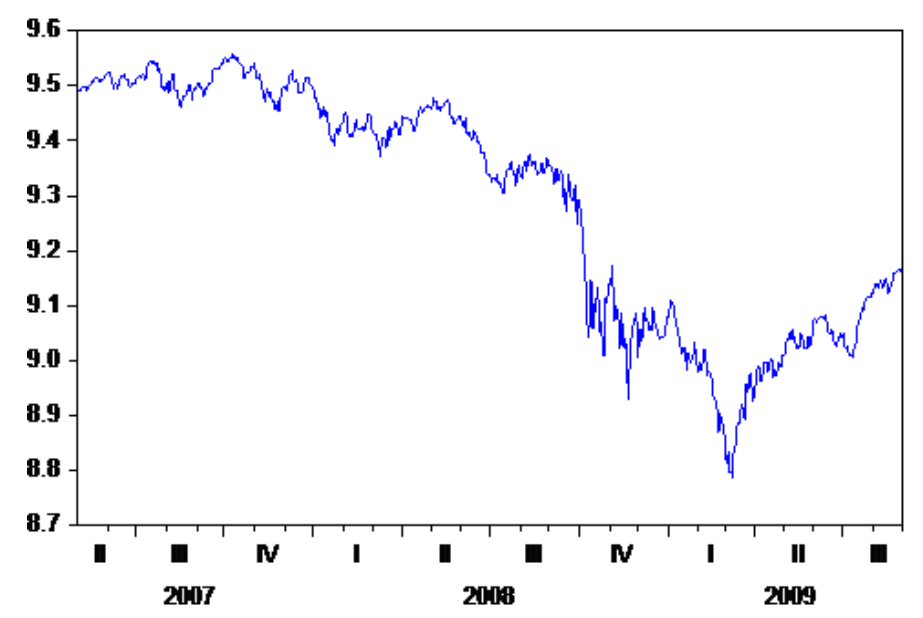

LCAC

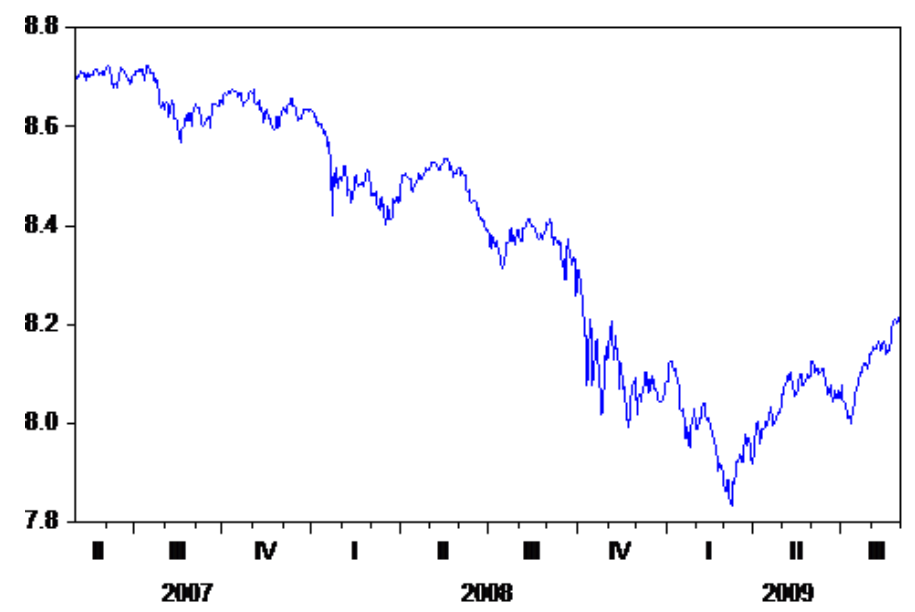

Figure 8: The co-movements between American and French stock returns in 2008

Both series in levels seem to have a downward trend. Regarding the unit root tests, there are both $\mathrm{I}(1)$, we can then suppose there is a constant term in the error correction model. 
Table 11: Trace test results

\begin{tabular}{lcccc}
\hline \hline Hypothesized & & Trace & 0.05 & \\
Number of CE(s) & Eigenvalue & Statistic & Critical Value & $p$-value \\
\hline None & 0.032 & $\mathbf{2 0 . 7 3 8}$ & $\mathbf{1 5 . 4 9 4}$ & 0.007 \\
At most one & 0.001 & $\mathbf{1 . 0 7 7}$ & $\mathbf{3 . 8 4 1}$ & 0.299 \\
\hline \hline
\end{tabular}

Sample: 5/04/2007 - 8/31/2009

$20.7>15.5 \rightarrow$ We reject the null hypothesis of no cointegration relationship. $1.07<3.8 \rightarrow$ We accept the null hypothesis that there is at most one long-run relationship between the two variables.

Table 12: Vector Error Correction Estimates

\begin{tabular}{lcc}
\hline \hline Cointegrating Equation & $z_{t-1}$ \\
\hline \hline$L C A C_{t-1}$ & 1 & \\
$L D J_{t-1}$ & -1.185 & \\
& $(0.056)$ & \\
Intercept & 2.649 & \\
\hline \hline Error Correction & $\Delta L C A C$ & $\Delta L D J$ \\
\hline \hline$z_{t-1}$ & -0.041 & 0.004 \\
& $(0.013)$ & $(0.018)$ \\
$\Delta L C A C_{t-1}$ & -0.456 & -0.044 \\
& $(0.040)$ & $(0.055)$ \\
$\Delta L C A C_{t-2}$ & -0.030 & -0.025 \\
& $(0.027)$ & $(0.038)$ \\
$\Delta L D J_{t-1}$ & 0.827 & -0.159 \\
& $(0.033)$ & $(0.046)$ \\
$\Delta L D J_{t-2}$ & 0.355 & -0.092 \\
& $(0.044)$ & $(0.061)$ \\
Intercept & -0.0005 & -0.0007 \\
& $(0.0005)$ & $(0.0007)$ \\
\hline \hline Sample $5 / 7 / 2007-8 / 31 / 2009(606$ observations $)$ \\
R-squared & 0.58 & 0.04 \\
$F$-stat & 170.60 & 5.11 \\
AIC & -5.77 & -5.13 \\
\hline \hline
\end{tabular}

Notes: standard errors are reported in brackets. 
- The Great Depression

Table 13: Trace test results

\begin{tabular}{lcccc}
\hline \hline Hypothesized & & Trace & 0.05 & \\
Number of CE(s) & Eigenvalue & Statistic & Critical Value & $p$-value \\
\hline None & 0.015 & $\mathbf{7 . 1 6 9}$ & $\mathbf{1 5 . 4 9 7}$ & 0.558 \\
At most one & 0.008 & 2.541 & 3.841 & 0.111 \\
\hline \hline
\end{tabular}

Sample: 2/05/1929 - 3/31/1930

$27.17<15.5 \rightarrow$ We accept the null hypothesis at the $5 \%$ confidence level, thus there is no cointegration.

Table 14: Pairwise Granger causality test

\begin{tabular}{lcccccc}
\hline Number of lags & $p=1$ & $p=2$ & $p=3$ & $p=4$ & $p=5$ & $p=6$ \\
\hline$R_{D J} \rightarrow R_{C A C}$ & $<0.01$ & 0.481 & 0.264 & 0.377 & 0.374 & 0.451 \\
$R_{C A C} \rightarrow R_{D J}$ & $<0.01$ & $<0.01$ & $<0.01$ & $<0.01$ & $<0.01$ & $<0.01$ \\
\hline \multicolumn{7}{c}{ Notes: the probabilities of incorrectly rejecting the null of no causality are reported above. }
\end{tabular}


Table 15: VAR(3) Estimates

\begin{tabular}{lcc} 
& $\Delta L D J$ & $\Delta L H C A C$ \\
\hline \hline$\Delta L D J_{t-1}$ & 0.215 & 0.184 \\
$\Delta L D J_{t-2}$ & $-0.056)$ & $(0.034)$ \\
& $(0.056)$ & -0.007 \\
$\Delta L D J_{t-3}$ & 0.265 & $0.034)$ \\
& $(0.058)$ & $(0.035)$ \\
$\Delta L H C A C_{t-1}$ & -0.131 & -0.227 \\
& $(0.097)$ & $(0.058)$ \\
$\Delta L H C A C_{t-2}$ & -0.129 & -0.014 \\
& $(0.099)$ & $(0.059)$ \\
$\Delta L H C A C_{t-3}$ & 0.071 & -0.074 \\
& $(0.092)$ & $(0.055)$ \\
Intercept & -0.0004 & -0.0006 \\
& $(0.0001)$ & $(0.0007)$ \\
\hline \hline Sample 2/07/1929-3/31/1930 & $(298$ obs. $)$ \\
R-squared & 0.19 & 0.14 \\
$F$-stat & 12.11 & 8.21 \\
AIC & -4.83 & -5.84 \\
\hline \hline
\end{tabular}

Notes: standard errors are reported in brackets.

Table 16: VAR(1) Estimates

\begin{tabular}{lcc} 
& $\Delta L D J$ & $\Delta L H C A C$ \\
\hline \hline$\Delta L D J_{t-1}$ & 0.106 & 0.184 \\
& $(0.057)$ & $(0.032)$ \\
$\Delta L H C A C_{t-1}$ & -0.259 & -0.255 \\
& $(0.095)$ & $(0.052)$ \\
Intercept & -0.0004 & -0.0005 \\
\multicolumn{2}{c}{$(0.001)$} & $(0.0007)$ \\
\hline \hline Sample 2/05/1929-3/31/1930 (300 obs.) \\
R-squared & 0.03 & 0.15 \\
F-stat & 5.04 & 26.48 \\
AIC & -4.67 & -5.82 \\
\hline \hline
\end{tabular}

Notes: standard errors are reported in brackets. 